\title{
AVALIAÇÃO DA QUALIDADE AMBIENTAL DAS PRAIAS DA ILHA DE ITAPARICA, BAÍA DE
} TODOS OS SANTOS, BAHIA

\author{
Environmental quality of the beaches of the island of Itaparica, Todos os Santos Bay, Bahia
}

Jacqueline Lopes de Souza Universidade Federal da Bahia, Salvador, Bahia, Brasil jackllopes@hotmail.com

Iracema Reimão Silva

Universidade Católica de Salvador, Salvador, Bahia, Brasil iracemars@yahoo.com.br

Artigo recebido em 10/07/2014 e aceito para publicação em 14/11/2015

RESUMO: Considerando que a qualidade ambiental de uma praia representa um dos principais fatores para sua atratividade para fins recreacionais, o presente trabalho tem como objetivo principal avaliar a qualidade ambiental das praias mais frequentadas na ilha de Itaparica. Com essa finalidade, foram coletadas amostras de água, areia e de resíduos sólidos durante o verão (alta estação) e o inverno (baixa estação). As análises de Coliformes Termotolerantes e Totais nos dois períodos analisados caracterizam as praias de Ponta de Itaparica, Ponta de Areia, Mar Grande e Conceição como próprias para recreação de contato primário, enquanto a praia de Barra Grande foi enquadrada como própria somente no período de baixa estação. Já a análise destes parâmetros para a areia indicou que todas as praias, na alta estação, estavam próprias para atividades de contato primário, contudo, no período de baixa estação, apenas a praia de Barra Grande obteve um resultado satisfatório. Foi encontrada grande quantidade de lixo nas praias amostradas, especialmente na alta estação, com o predomínio dos plásticos dentre os itens coletados. Os resultados mostram que a deficiência de infraestrutura de saneamento ambiental e o uso desordenado do seu litoral são os principais responsáveis pelo comprometimento da qualidade ambiental das praias de ilha de Itaparica.

Palavras-chaves: avaliação ambiental; balneabilidade; lixo marinho.

ABSTRACT: The environmental quality of a beach represents one of the main factors for its attractiveness for recreational purposes. The present study had the main objective of evaluating the environmental quality of some of the most frequented beaches in the island of Itaparica, based on analyses of their balneability, sand quality and occurrence of marine litter. The Thermotolerant and Total Coliforms analyses during both periods characterized the beaches of Ponta de Itaparica, Ponta de Areia, Mar Grande andConceiçãoas adequate for primary contact recreation, while the Barra Grande beach was only considered adequate during the low season. When considering the analysis of these parameters for the sand, all beaches during the high season were adequate for primary contact activities, however, during the low season, only Barra Grande 
beach obtained a satisfactory result. A large amount of litter was found in the beaches sampled, particularly during the high season. Among the residues, plastic items predominated. The results indicate that the deficiency in the environmental sanitation infrastructure and disorderly use of the coast are the main responsible factors for the compromised environmental quality of the beaches of the island of Itaparica.

Keywords: environmental evaluation; balneability; marine litter.

\section{INTRODUÇÃO}

As ações do homem sobre a natureza causam impactos que muitas vezes são superiores à capacidade de suporte do meio natural. Um exemplo disso é a urbanização desordenada do litoral, podendo causar descaracterização ambiental, degradação e desestruturações irreversíveis (CORIOLANO, 2001). Estas ações podem provocar a poluição destes ambientes, inviabilizando o seu uso e acarretando graves problemas ambientais. A poluição representa um dos principais problemas para a maior parte das costas em todo o mundo, podendo trazer graves consequências ambientais e econômicas. Algumas pesquisas (WILLIAMS e NELSON, 1997; BLAKEMORE e WILLIAMS, 1998; MORGAN, 1999) indicam que, para a maioria das pessoas consultadas, a qualidade da água é o aspecto mais importante para o uso da praia.

Nas últimas décadas tem aumentado bastante as preocupações relativas à presença do lixo no ambiente marinho, bem como aos diversos problemas a ele associados (ARAÚJO e COSTA, 2003; UNEP, 2009). A presença de lixo marinho (resíduo sólido de origem antropogênica encontrado em ambiente costeiro e marinho), além de poluir a areia e as águas costeiras, ocasionando o risco de contaminação por doenças de pele e outras enfermidades, cria um desagradável efeito visual, diminuindo a beleza cênica das praias e desmotivando a presença dos turistas (MIDAGLIA, 2001). O lixo deixado nas praias também altera a vida dos microrganismos e microfauna da areia e atrai a presença de animais transmissores de doenças, como ratos e urubus. A limpeza e o manejo das praias são vistos como condições essenciais para manter a sua atratividade (BIRD, 1996). Segundo Morgan (1999), a ausência de escombros e lixos na praia e a qualidade da água para o banho estão entre as exigências prioritárias dos turistas para o uso recreacional das praias. Além disso, esse tipo de poluição pode comprometer a qualidade dos ecossistemas costeiros e marinhos.

Segundo o Glossary of Environment Statistics (1997), Valle (1995), Bitar (2004) e Fulgêncio (2007), a qualidade ambiental representa o estado das condições do meio ambiente segundo um conjunto de normas e padrões ambientais pré-estabelecidos sejam eles de âmbito local, regional, nacional ou internacional, que assegurem a estabilidade das relações ambientais nos ecossistemas. Enfatizando a relação do homem com o meio ambiente, a European Environment Agency define qualidade ambiental como um conjunto de propriedades e características do meio ambiente que incide sobre os seres humanos e também sobre outros organismos (EEA, 2010).

Existe uma série de instrumentos, critérios e normas voltadas especificamente para analisar a qualidade das praias. Estas ferramentas há décadas vêm sendo utilizadas por pesquisadores e órgãos ambientais de várias partes do mundo, com o objetivo de fornecer um melhor diagnostico ambiental das praias (HOLDEN, 2000; ROCA et. al., 2009). Esforços vêm sendo feitos para melhorar os procedimentos de avaliação e de gestão das praias (BENEDICT e NEUMANN, 2004; ROCA et. al., 2009; SILVA et. al., 2009).

Durante muito tempo, a qualidade destes ambientes foi monitorada apenas pela densidade de bactérias presentes em suas águas. Acreditava-se que a água era a principal fonte de transmissão de doenças nas praias (AFIFI et. al., 2000). Assim, diversos órgãos e instituições criaram critérios e parâmetros para classificar as praias apenas do ponto de vista da sua balneabilidade (BENEDICT e NEUMANN, 2004; ROCA et. al., 2009). Nos últimos anos, vêm crescendo a preocupação em incluir outras variáveis para definir a qualidade de uma praia e para preservar a saúde e o bem estar dos usuários. É necessário relacionar a qualidade das praias não apenas com a balneabilidade, mas também com os resíduos que 
os usuários e turistas produzem ou aqueles que são transportados pelas correntes marinhas, com a análise bacteriológica da areia, a ocupação desordenada da faixa de praia, entre outros.

A ilha de Itaparica apresenta uma vasta extensão litorânea, composta por mais de $40 \mathrm{~km}$ de praias, desempenha um importante papel de lazer e recreação para visitantes e para a população local e regional. Entretanto, a carência de gestão e planejamento do uso e ocupação dessas praias, associada à falta de monitoramento e ao descarte inadequado de efluentes líquidos e de resíduos sólidos, pode comprometer a qualidade recreacional e turística das praias da ilha de Itaparica.

Desta forma, este trabalho tem como objetivo principal avaliar a qualidade ambiental das praias mais frequentadas na ilha de Itaparica, a partir da análise de sua balneabilidade, qualidade da areia e ocorrência de resíduos sólidos (lixo marinho) nestas praias.

\section{CARACTERÍSTICAS GERAIS DA ÁREA DE ESTUDO}

A área de estudo compreende as praias de Ponta de Itaparica, Ponta de Areia, Mar Grande, Conceição e Barra Grande, localizadas na ilha de Itaparica, situada a sudoeste da Baía de Todos os Santos, estado da Bahia (Figura 1). Com aproximadamente 104 $\mathrm{km}$ de costa e contracosta, a ilha está dividida em dois municípios, Itaparica e Vera Cruz, que juntos possuem uma área de $240 \mathrm{~km}^{2}$ e uma população de cerca de 63.853 habitantes (IBGE, 2013).

Localizada sobre as rochas sedimentares que preenchem a Bacia Sedimentar do Recôncavo Baiano, a ilha de Itaparica é a maior ilha das 56 que compõem o arquipélago da Baía de Todos os Santos. A face da ilha voltada para a entrada da baía é circundada por recifes de corais, que se desenvolveram sobre as lajes (terraços de abrasão) que bordejam a ilha (DOMINGUEZ e BITTENCOURT, 2009).

O clima da Ilha de Itaparica é do tipo tropical quente-úmido, com médias anuais de temperatura em torno de $25,2^{\circ} \mathrm{C}$, com precipitação pluviométrica e evaporação em torno de $2.100 \mathrm{~mm}$ e $1.002 \mathrm{~mm}$ anuais, respectivamente (INMET, 1992). Tal clima, aliado às condições de fertilidade do solo, favorecem o desenvolvimento de tipologias vegetacionais costeiras do tipo Mata Atlântica, mangues e restingas.

$\mathrm{O}$ acesso à ilha, que dista cerca de $13 \mathrm{Km}$ de Salvador, pode ser feito pelo terminal marítimo de São Joaquim a partir dos sistemas ferry-boat e catamarã, partindo da capital baiana, até os terminais de Bom Despacho e Mar Grande,ou por terra pelas rodovias BR-101, BA-001 e BR-324 (Figura 1).

Segundo dados da Empresa Baiana de Água e Saneamento (EMBASA) a infraestrutura de esgotamento sanitário só existe em $40 \%$ da ilha, sendo o município de Itaparica o mais beneficiado com o serviço. Os dados mostram que, no município de Itaparica, $43 \%$ da população é atendida pelo Serviço de Esgotamento Sanitário, já em Vera Cruz apenas $20 \%$ da população possui o serviço (EMBASA, 2011).

Os municípios de Itaparica e Vera Cruz contam com apenas uma Estação de Tratamento, com capacidade para receber um pouco mais da metade do esgoto coletado nos dois municípios. Do esgoto coletado no município de Itaparica $54 \%$ é tratado, já em Vera Cruz, do total de esgoto coletado apenas 15\% passa pelo processo de tratamento (EMBASA, 2011). Desta forma, ainda é comum observar em muitas praias da ilha, principalmente no município de Vera Cruz, o lançamento inadequado de esgoto doméstico, podendo causar a contaminação da água e da areia, colocando em risco a saúde e o bem-estar dos usuários.

Segundo Nascimento (2012), atualmente, $53 \%$ da área dos primeiros cem metros de faixa costeira encontram-se ocupados por construções fixas e $28 \%$ de toda a sua extensão apresenta algum tipo de obra de engenharia (Figura 2). Não existem indústrias nesta faixa costeira adjacente à praia, a maior parte das construções é de uso residencial, seja residência fixa ou de veraneio, e estruturas de suporte aos usuários, como restaurantes e barracas de praia.

Como consequência desse mau uso da linha de costa, com construções próximas à linha de preamar de sizígia, podem ser vistos na ilha de Itaparica diversos trechos costeiros apresentando queda de muros de proteção à erosão e de outras construções (NASCIMENTO, 2012). 
Figura 1- Localização da Ilha de Itaparica e das praias estudadas.

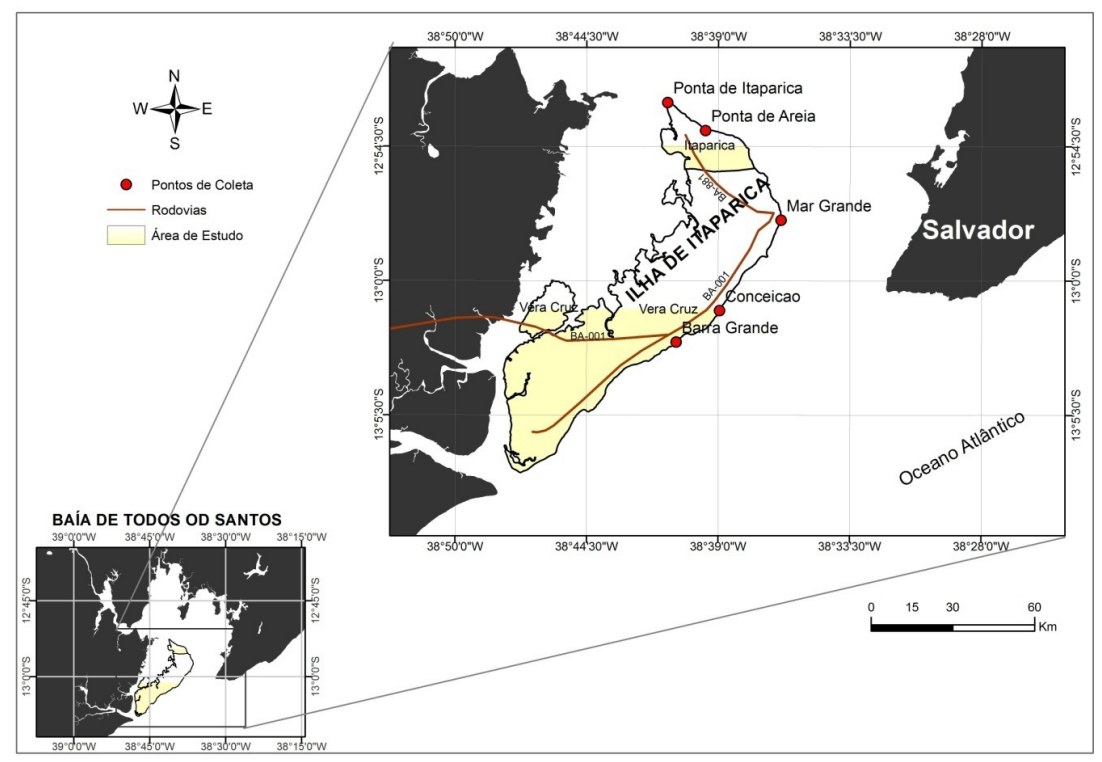

Fonte: BAHIA/SEI (2008), modificada pelos autores

Figura 2 - Construções fixas e muro de $p$

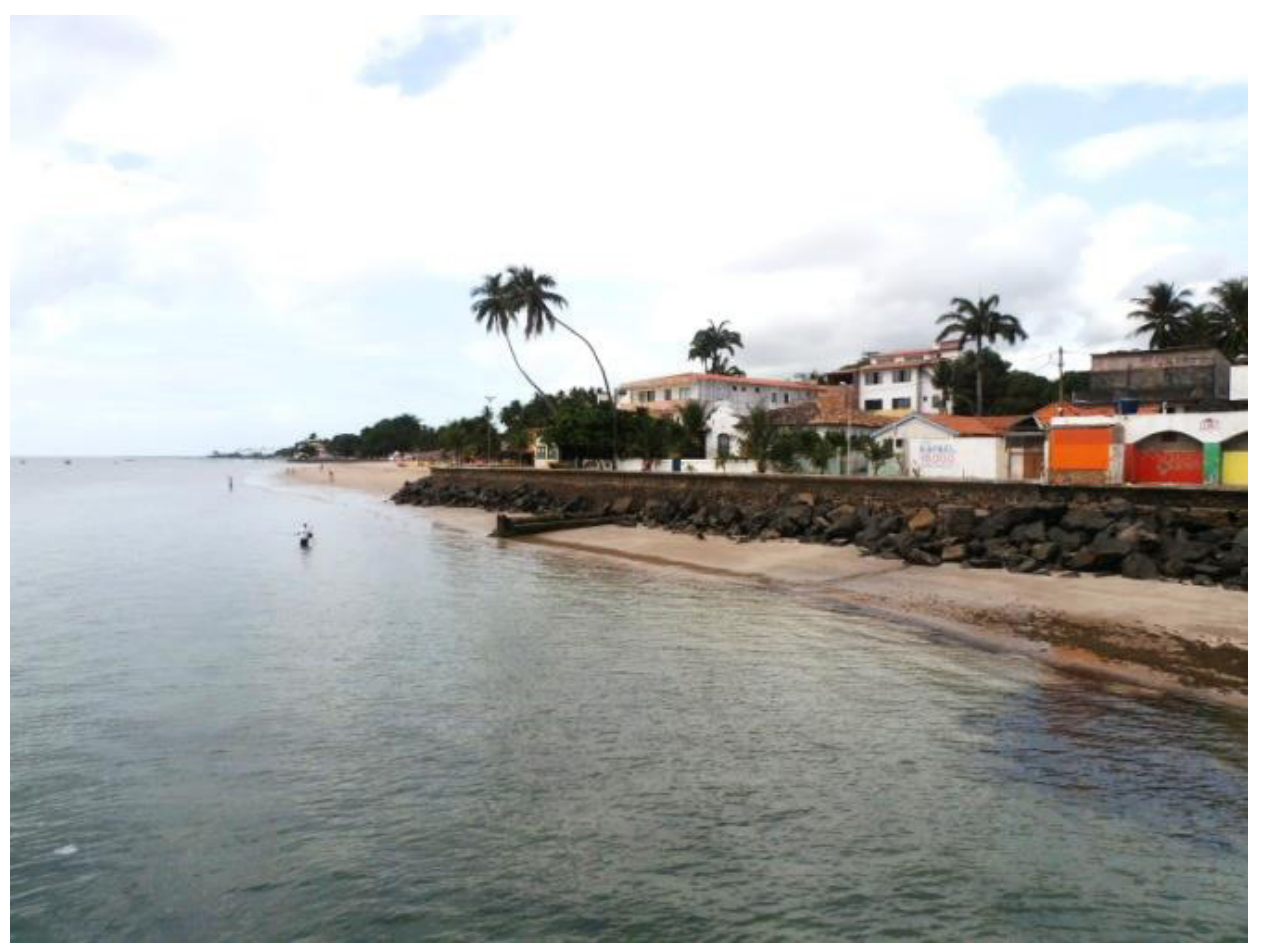

Fonte: Campanha de campo dos autores 


\section{MATERIAIS E MÉTODOS}

\section{Balneabilidade das Praias}

Os pontos de coleta das amostras em cada praia foram escolhidos levando-se em consideração a quantidades de banhistas concentrados em determinada área. Os parâmetros físico-químicos,
Temperatura e $\mathrm{pH}$, foram medidos in situ com a sonda multiparâmetros marca Horiba ${ }^{\circledR}$, modelo U52-G. Os procedimentos de coleta da água foram baseados na resolução CONAMA №. 274/00 e seus resultados foram comparados com os limites recomendados por essa mesma resolução e pelas resoluções CONAMA $N^{o} 20 / 86$ e No 357/05 (Quadro 1).

Quadro 01 - Enquadramento das águas quanto à balneabilidade segundo as Resoluções CONAMA nº 274/00 e no $20 / 86$.

\begin{tabular}{|l|l|l|l|}
\hline \multirow{4}{*}{ Própria } & Categoria & $\begin{array}{l}\text { Limite de Coliformes Fecais } \\
\text { (Termotolerantes }) \\
\text { NMP/100 ml }\end{array}$ & $\begin{array}{l}\text { Limite de Coliformes Totais } \\
\text { NMP/100 ml }\end{array}$ \\
\cline { 2 - 4 } & Excelente & $\begin{array}{l}\text { Máximo de } 250 \mathrm{em} 80 \% \text { ou mais do } \\
\text { tempo }\end{array}$ & $\begin{array}{l}\text { Máximo de } 1.250 \text { em } 80 \% \text { ou mais } \\
\text { do tempo }\end{array}$ \\
\cline { 2 - 4 } & Muito boa & $\begin{array}{l}\text { Máximo de } 500 \mathrm{em} 80 \% \text { ou mais do } \\
\text { tempo }\end{array}$ & $\begin{array}{l}\text { Máximo de } 2.500 \mathrm{em} 80 \% \text { ou mais } \\
\text { do tempo }\end{array}$ \\
\cline { 2 - 4 } & Satisfatória & $\begin{array}{l}\text { Máximo de } 1.000 \text { em } 80 \% \text { ou mias } \\
\text { do tempo }\end{array}$ & $\begin{array}{l}\text { Máximo de } 5.000 \text { em } 80 \% \text { ou mais } \\
\text { do tempo }\end{array}$ \\
\hline \multirow{2}{*}{ Imprópria } & Imprópria & $\begin{array}{l}\text { Superior a } 1.000 \text { em mais de 20\% do } \\
\text { tempo ou superior a 2.500 na última } \\
\text { amostragem }\end{array}$ & $\begin{array}{l}\text { Superior a } 5.000 \text { em mais de 20\% } \\
\text { do tempo }\end{array}$ \\
\hline
\end{tabular}

Fonte: CONAMA (1996, 2005), organização dos autores

As coletas foram realizadas em dois períodos: durante a alta estação (mês de Janeiro de 2013) e durante a baixa estação (mês de Julho de 2013). Foram coletadas 10 amostras em cada ponto, somando-se 50 amostras em cada período, sendo elas 25 para análise bacteriológica e 25 para análise de Nitrato. O total de amostras coletadas nos dois períodos analisados foram 100 amostras. A amostragem foi efetuada em local que apresentou a isóbatade 1 metro. Optou-se por essa profundidade na tentativa de padronizar o método de amostragem em todos os pontos, devese considerar, contudo que, para diferentes épocas do ano e em diferentes níveis de maré, existe uma variação nos locais de coleta correspondentes a esta cota batimétrica.

Para a coleta de amostras de água para análise microbiológica foram utilizados frascos de vidro de $500 \mathrm{ml}$ estéril e para as análises de Nitrato foram utilizados frascos de polietileno de $500 \mathrm{ml}$ previamente descontaminados em laboratório, ambas coletadas manualmente, utilizando luvas descartáveis.

As amostras foram identificadas com o nome da praia e data da coleta e em seguida acondicionadas em um recipiente refrigerado e encaminhado imediatamente para o laboratório LABDEA/UFBA e PLASMA/UFBA, onde foram submetidas à análise bacteriológica através do método do NMP (Número MaisProvável)deColiformes TotaiseTermotolerantes utilizando a técnica de tubos múltiplos. O íon Nitrato foi determinado por espectrofotometria, onde os resultados foram comparados com os limites estabelecidos pela resolução CONAMAN ${ }^{\circ}$ 357/05. 


\section{Qualidade da Areia}

A metodologia de coleta da areia foi baseada nos procedimentos determinados pela Agência Portuguesa do Ambiente (APA, 2011). Os resultados foram comparados com os limites recomendados pelas resoluções CONAMA No 274/00 e No 20/86, devido à inexistência de legislação nacional e internacional para areia.

Foi considerado um transecto paralelo à linha de costa que se subdividiu em 03 pontos equidistantes do qual se procedeu à coleta de uma pequena porção de areia, que depois de homogeneizada, constituiu uma amostra composta, representativa da área em estudo.

A coleta foi realizada, também em dois períodos (meses de Janeiro e Julho de 2013) em cada ponto a uma profundidade entre 05 e $15 \mathrm{~cm}$, utilizando para o efeito, luvas e sacos esterilizados. As amostras foram identificadas com o nome da praia e data da coleta e em seguida acondicionadas em um recipiente refrigerado. Logo após a coleta as amostras foram encaminhadas imediatamente para o laboratório SENAI CETIND, onde foram submetidas à análise bacteriológica através do método do NMP (Número Mais Provável) de coliformes totais e termotolerantes pela técnica de tubos múltiplos.

\section{Resíduos Sólidos (Lixo Marinho)}

A coleta dos resíduos sólidos também foi realizada em dois períodos, meses de Janeiro e Julho de 2013. Em cada praia estudada foi traçado um transecto longitudinal de $10 \mathrm{~m}$ de largura que se estendeu da linha d'água até a base do cordão duna ou de qualquer outra estrutura que denotasse o limite superior do ambiente praial. Todo o lixo encontrado foi coletado manualmente, incluindo apenas itens maiores que $1 \mathrm{~cm}$, visando uma otimização no processo de detecção visual (OLIVEIRA et. al., 2011).

A avaliação do lixo marinho foi baseada na sua qualificação (classificação distinguindo categorias específicas) e quantificação. A composição do estoque coletado foi subdividida em relação ao material de origem (borracha, espuma, isopor, metal, nylon, papel, plástico, tecido, embalagens Tetra Pak e vidro) e à sua utilidade original (UNEP/IOC/FAO, 1989; SOARES et. al., 2011).

\section{RESULTADOS}

No período de alta estação a temperatura da água das praias analisadas oscilou em torno de 26,18 a $32,34{ }^{\circ} \mathrm{C}$, média de $29,26{ }^{\circ} \mathrm{C}$, e, na baixa estação, de 24,45 a $28,23{ }^{\circ} \mathrm{C}$, com média de $26,34{ }^{\circ} \mathrm{C}$ (Figura 3). $\mathrm{O} \mathrm{pH}$ da água variou de 7,65 a 8,82 , com média de 8,23 na alta estação. Neste período, nas praias de Ponta de Areia (P2), Mar Grande (P3), Conceição (P4) e Barra Grande (P5) o pH oscilou de de 7,74 a 8,21 e na praia de Ponta de Itaparica $(\mathrm{P} 1)$ a variação ocorreu na faixa de 7,65 a 8,82.Na baixa estação o $\mathrm{pH}$ se apresentou dentro da faixa considerada ideal pelo CONAMA, variando de 8,27 a 8,50 e média de 8,38 (Figura 4). 

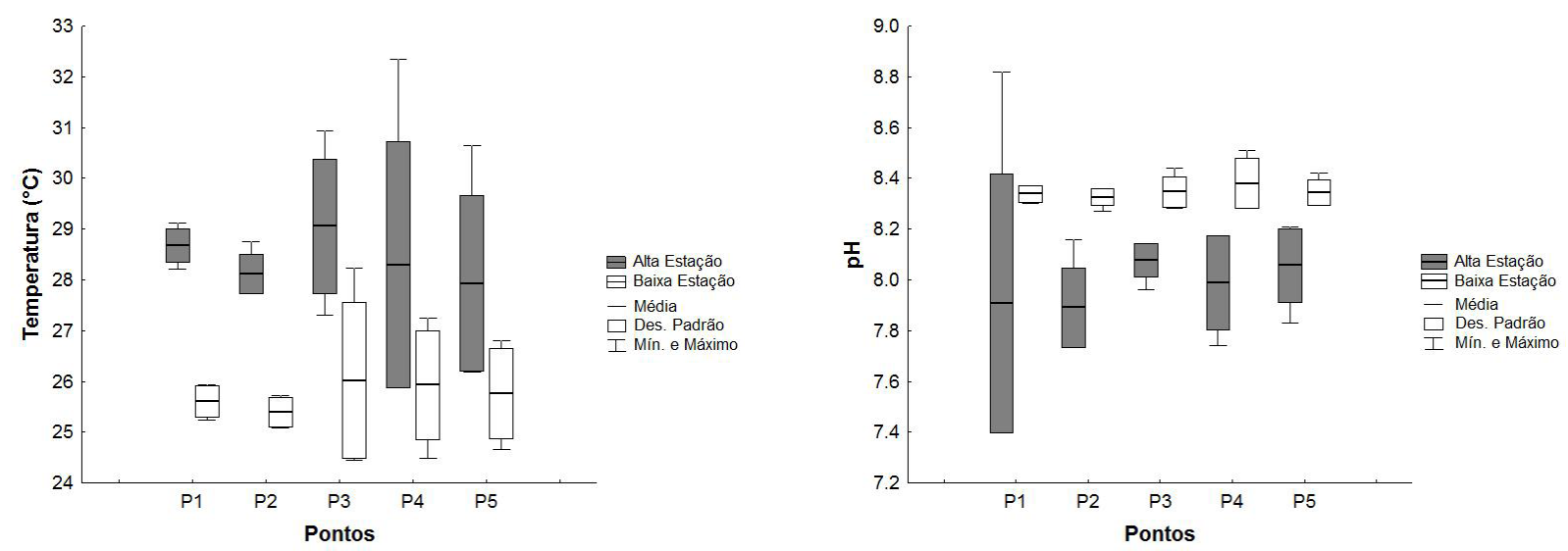

Fonte: Resultados das análises feitas pelos autores

Os resultados encontrados na alta estação, utilizando os parâmetros bacteriológicos de Coliformes Termotolerantes e Coliformes Totais, nas amostras de água nas praias da Ilha de Itaparica, indicaram:

i) Para as praias de Ponta de Itaparica, Ponta de Areia e Conceição, em todas as amostras, índices de Coliformes Termotolerantes e Totais abaixo do limite permitido pelas Resoluções CONAMA ${ }^{\circ}$ 274/00 e $\mathrm{N}^{o}$ 20/86, sendo, portanto, consideradas próprias para banho. Além disso, estas praias tiveram suas águas enquadradas na categoria de excelentes, pois apresentaram valores inferiores a $250 \mathrm{NMP}$ de Coliformes Termotolerantes e 1.250 NMP de Coliformes Totais em $100 \mathrm{ml}$ de água, em $80 \%$ das amostras analisadas;

ii) A praia de Mar Grande, na alta estação, foi qualificada como própria para banho e suas águas foram enquadradas na categoria de muito boa, uma vez que $80 \%$ das amostras analisadas apresentaram valores inferiores a 500 NMP de Coliformes Termotolerantes e 2.500 NMP de Coliformes Totais em $100 \mathrm{ml}$ de água, para o período analisado;

iii) Dentre as 05 (cinco) amostras de água coletadas na praia de Barra Grande, duas apresentaram alta concentração de Coliformes Totais, caracterizando-a como imprópria para recreação de contato primário no período analisado. Segundo a resolução CONAMA n ${ }^{\circ}$ 20/86, a praia é considerada imprópria para atividades recreacionais quando, em um conjunto de amostras obtidas em 05 (cinco) ou mais coletas, realizadas no mesmo período e local, há Coliformes Totais superiores a 5.000 NMP em mais de $20 \%$ das amostras. Além disso, em uma das amostras também foram encontrados altos valores de Coliformes Termotolerantes.

A concentração de Nitrato na alta estação variou de 0,0 a $4,53 \mathrm{mg} / \mathrm{L}-\mathrm{N}$ (média de $0,25 \mathrm{mg}$ / L-N). Das 25 amostras analisadas $12 \%$ estavam acima do limite permitido pela Resolução CONAMA $\mathrm{n}^{o} 357 / 05$ que é de $0,40 \mathrm{mg} / \mathrm{L}-\mathrm{N}$. As amostras que apresentaram valores acima do limite foram coletadas nas praias de Ponta de Areia, Conceição e Barra Grande. Elevadas concentrações de Nitrato, podem causar graves problemas aos ecossistemas aquáticos, trazendo prejuízos a todos que se beneficiam do recurso (MAGINI et. al., 2007).

Na baixa estação, os resultados encontrados, utilizando os mesmo parâmetros bacteriológicos, indicaram que:

i) Os pontos analisados nas praias de Ponta de Itaparica, Ponta de Areia, Conceição e Barra Grande apresentaram, em todas as amostras, índices de Coliformes Termotolerantes e Totais abaixo do limite permitido pelas Resoluções CONAMA ${ }^{\circ}$ $274 / 00$ e $N^{\circ} 20 / 86$, portanto, foram consideradas próprias para banho;

ii) A praia de Mar Grande foi qualificada 
como própria, todavia, em uma das amostras foram encontrados níveis de Coliformes Totais acima do permitido pela Resolução CONAMA n ${ }^{\circ} 20 / 86$;

iii) As águas das praias de Ponta de Itaparica e Mar Grande foram enquadradas na categoria de excelente em relação aos níveis de Coliformes Termotolerantes e Satisfatória em relação aos Coliformes Totais. Já as praias de Ponta de Areia, Conceição e Barra Grande tiveram suas águas enquadradas na categoria de excelente em relação aos dois parâmetros bacteriológicos.

Embora todas as praias analisadas estejam próprias para recreação de contato primário em relação aos parâmetros bacteriológicos, na baixa estação, nas praias de Ponta de Areia, Mar Grande, Conceição e Barra Grande, foram constatados altas concentrações de Nitrato, caracterizando presença de efluentes domésticos nesses ambientes. A concentração de Nitrato, na baixa estação, variou de 0,0 a $5,84 \mathrm{mg} / \mathrm{L}-\mathrm{N}$ (média de 1,45 mg/L-N). Das 25 amostras, $68 \%$ estavam acima do limite permitido pela Resolução CONAMAN ${ }^{\circ} 357 / 05$ que é de 0,40 $\mathrm{mg} / \mathrm{L}-\mathrm{N}$.

A Resolução CONAMA no 274/00 não estabelece limites de balneabilidade para esse elemento, no entanto, considera que as águas serão consideradas impróprias quando no trecho avaliado for verificada a presença de resíduos ou despejos, sólidos ou líquidos, inclusive esgotos sanitários, além da ocorrência de outros fatores que sejam capazes de oferecer risco à saúde e o bem-estar humano, a exemplo das altas concentrações de Nitrato encontradas nas praias de Ponta de Areia, Mar Grande, Conceição e Barra Grande.

As amostras de areia coletadas nas praias de Ponta de Itaparica, Ponta de Areia, Mar Grande, Conceição e Barra Grande, na alta estação, apresentaram índice de Coliformes Termotolerantes e Totais abaixo do limite permitido, tomando-se como referências as Resoluções CONAMA $\mathrm{N}^{\circ}$ 274/00 e N $^{o} 20 / 86$, sendo, portanto, consideradas próprias para atividades de contato primário no período analisado. Todas as praias estudadas foram enquadradas na categoria de excelentes, em relação a estes parâmetros.

Já os resultados encontrados na areia das praias durante a baixa estação demonstraram uma alta concentração de Coliformes Termotolerantes e Totais nas praias de Ponta de Itaparica, Mar Grande e Conceição, o que coloca a areia dessas três praias como impróprias, segundo as Legislações adotadas como referência. Já a praia de Ponta de Areia apresentou-se própria para atividades recreacionais de contato primário com relação aos níveis de Coliformes Totais, mas imprópria em relação aos Coliformes Termotolerantes. A praia de Barra Grande teve sua areia enquadrada na categoria de própria em relação aos dois parâmetros analisados.

Com relação aos resíduos sólidos, no período de alta estação o número total de itens coletados foi de 2.220, sendo 326 na praia de Ponta de Itaparica, 545 na praia de Ponta de Areia, 438 na Praia de Mar Grande, 568 na praia de Conceição e 343 na Praia de Barra Grande. Deste total, 49\% eram plásticos, 25\% metal, $11 \%$ papel, $4 \%$ vidro e $11 \%$ outros materiais. Os dez itens mais encontrados nas praias analisadas no período de alta estação estão descritos no Quadro 2.

As coletas realizadas na baixa estação somaram-se 508 itens, apresentando uma grande diferença no número de itens coletados em relação à campanha anterior. Desse total, 91 itens foram coletados na praia de Ponta de Itaparica, 86 na praia de Ponta de Areia, 57 na praia de Mar Grande, 138 na praia de Conceição e 135 na praia de Barra Grande. O percentual dos itens amostrados indicou que 59\% eram plásticos, $14 \%$ fragmentos de isopor, $9 \%$ metal, $7 \%$ papel e $11 \%$ outros materiais. Os dez itens mais encontrados nas praias analisadas no período de baixa estação estão descritos no Quadro 3. 
Quadro 2 - Os dez itens mais encontrados nas praias analisadas no período de alta estação

\begin{tabular}{|l|l|l|l|l|l|l|}
\hline & $\begin{array}{l}\text { P. Ponta de } \\
\text { Itaparica }\end{array}$ & $\begin{array}{l}\text { P. Ponta de } \\
\text { Areia }\end{array}$ & $\begin{array}{l}\text { P. Mar } \\
\text { Grande }\end{array}$ & P. Conceição & $\begin{array}{l}\text { P. Barra } \\
\text { Grande }\end{array}$ & $\begin{array}{l}\text { Total/ } \\
\text { Itens }\end{array}$ \\
\hline 1. Tampinha de cerveja & 64 & 141 & 31 & 258 & 06 & 500 \\
\hline 2. Copo Descartável & 53 & 68 & 122 & 24 & 144 & 411 \\
\hline 3. Canudinho & 46 & 17 & 43 & 35 & 12 & 153 \\
\hline 4. Papel Acarajé/Lanches & 25 & 33 & 35 & 53 & 20 & 166 \\
\hline 5. Bituca de Cigarro & 12 & 50 & 05 & 28 & 11 & 106 \\
\hline 6. Colher e Garfo Descartável & 15 & 29 & 10 & 28 & 03 & 85 \\
\hline 7. Fragmentos de Vidro & ---- & 82 & 01 & ---- & ---- & 83 \\
\hline 8. Tampa de Refrigerante & 14 & 38 & 10 & 12 & 08 & 82 \\
\hline $\begin{array}{l}\text { 9. Embalagem de Geladinho e } \\
\text { Picolé }\end{array}$ & 06 & 06 & 28 & 21 & 12 & 73 \\
\hline 10. Palito de Churrasco & 14 & 01 & 13 & 29 & 05 & 62 \\
\hline
\end{tabular}

Fonte: Campanhas de campo dos autores

Quadro 3 - Os dez itens mais encontrados nas praias analisadas no período de baixa estação

\begin{tabular}{|l|l|l|l|l|l|l|}
\hline Itens & $\begin{array}{l}\text { P. Ponta de } \\
\text { Itaparica }\end{array}$ & $\begin{array}{l}\text { P. Ponta } \\
\text { de Areia }\end{array}$ & $\begin{array}{l}\text { P. Mar } \\
\text { Grande }\end{array}$ & $\begin{array}{l}\text { P. } \\
\text { Conceição }\end{array}$ & $\begin{array}{l}\text { P. Barra } \\
\text { Grande }\end{array}$ & $\begin{array}{l}\text { Total/ } \\
\text { Itens }\end{array}$ \\
\hline 1. Isopor - pescadores & 02 & 06 & 01 & 13 & 49 & 69 \\
\hline 2. Copos descartáveis & 06 & 14 & 15 & 06 & 03 & 44 \\
\hline 3. Tampa de cerveja & 16 & 04 & 03 & 18 & ---- & 41 \\
\hline 4. Palinetes & ---- & 01 & 02 & 17 & 17 & 37 \\
\hline 5. Tampa de refrigerante & 06 & 02 & 04 & 15 & 10 & 37 \\
\hline 6. Canudos & 12 & 01 & 04 & 11 & 06 & 34 \\
\hline 7. Bituca de cigarro & 06 & 12 & ----- & 05 & 10 & 33 \\
\hline 8. Papel de Bala & 09 & 01 & 02 & 01 & 06 & 19 \\
\hline 9. Palito de Pirulito & 02 & 01 & ---- & 12 & 04 & 19 \\
\hline $\begin{array}{l}\text { 10. Garrafas pet (utilizadas para iluminar } \\
\text { os barcos) }\end{array}$ & ----- & 11 & 02 & 01 & 02 & 16 \\
\hline
\end{tabular}

Fonte: Campanhas de campo dos autores 


\section{DISCUSSÕES}

A Resolução CONAMAn ${ }^{\circ}$ 357/05 estabelece para águas salinas um $\mathrm{pH}$ com faixa de variação entre 6,5 a 8,5 , dentro da qual o $\mathrm{pH}$ pode oscilar, sem ocasionar riscos para a saúde dos banhistas. Os resultados mostram que, exceto a praia de Ponta de Itaparica, do qual foi registrado no período de alta estação um pH máximo de 8,82 , todos os pontos analisados, independente do período, estão dentro dos padrões estabelecidos pela referida lei.

Segundo Mendes e Oliveira (2004), na maior parte dos casos, a gama de variação dos valores do $\mathrm{pH}$ das águas superficiais, situa-se entre 6,5 e 8,5, entretanto, podem, como consequência da atividade biológica das algas, apresentar, especialmente no verão, valores de $\mathrm{pH}$ elevados, como foi verificado na praia de Ponta de Itaparica. O elevado valor do
pH na água da praia, pode ocasionar nos usuários irritação da pele e dos olhos após o banho.

Os altos índices de Coliformes encontrados na água da praia de Mar Grande, nos dois períodos de coleta, podem estar relacionados ao lançamento de efluentes domésticos no rio da Ilhota, que deságua nesta praia (Figura 5). Além disso, no período de baixa estação ocorreram chuvas no dia anterior à coleta. Segundo a CETESB (2004), dentre os fatores que causa interferência na qualidade da água das praias, uma das principais é a ocorrência de chuvas, pois os esgotos, lixões e outros detritos são carreados para as praias através de galerias, córregos e canais de drenagem, produzindo um aumento considerável na densidade de bactérias presentes na água.

Figura 5 - Rio da Ilhota na praia de Mar Grande

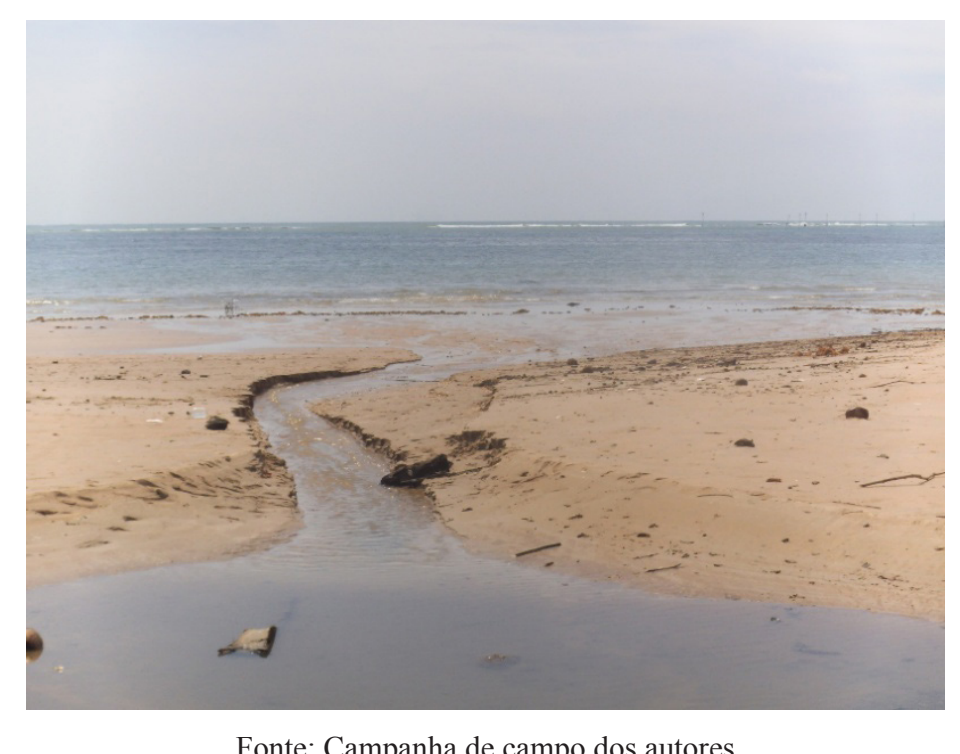

Na praia de Barra Grande, durante o período de alta estação, também foram constatados alta concentração de Coliformes Totais, o que colocou essa praia na categoria de imprópria. A alta concentração desses Coliformes pode estar associada ao esgoto doméstico, já que, nesta praia, foram observadas emissões pontuais de efluentes provenientes de algumas barracas e residências (Figura 6).

$\mathrm{Na}$ alta estação todas as praias analisadas tiveram concentrações de Nitrato muito baixas. Já na baixa estação, foram detectadas altas concentrações desse elemento nas amostras de água das praias de Ponta de Areia, Mar Grande, Conceição e Barra Grande. A alta concentração de Nitrato na água das praias indica elevado nível de contaminação dessa água por esgoto doméstico, o que coloca em risco a saúde e o bem-estar dos banhistas. Os períodos de baixa estação coincidem com os períodos mais 
chuvosos e, assim, mais propensos à contaminação pelas águas de escoamento superficial. Isso ocorre especialmente devido às precárias condições de saneamento encontradas na maior parte da ilha e à retirada de vegetação e alteração dos ecossistemas de manguezais e áreas úmidas. Estes ecossistemas ajudam no processo de ciclagem e filtragem de poluentes, além de contribuírem para o equilíbrio do sistema hídrico local.

A alteração da paisagem natural e seus ecossistemas e a construção de estruturas rígidas ao longo do litoral da ilha de Itaparica contribuiu também para intensificar o processo de erosão costeira. Estas estruturas impedem o livre recuo da faixa arenosa e acabam acarretando a reflexão das ondas incidentes, que escavam ainda mais o perfil praial, retirando cada vez mais areia.

Diniz (2002) destaca que as correntes marinhas favorecem a dispersão de águas poluídas. Além disso, a não detecção muitas vezes de altas concentrações de Coliformes e Nitrato nas amostras de água pode estar associada com a elevada diluição do ambiente, que acaba contribuindo para a manutenção de uma concentração mínima aceitável.

Recomenda-se ainda que estudos posteriores considerem também o Fósforo, não analisado na atual pesquisa, já que este elemento pode ajudar a relacionar o Nitrato com os impactos nos ambientes aquáticos.

Desta forma, segundo Manicini e colaboradores (2005), os microrganismos geralmente conseguem sobreviver mais tempo na areia do que na água, devido ao processo de bioacumulação de matéria orgânica, que serve de fonte de carbono, nitrogênio e sais para a proliferação desses microrganismos. O lixo deixado pelos usuários, tais como, copos descartáveis, vidro, sacolas plásticas, canudos, bituca de cigarro, garrafas pet, entre outros, favorecem também a sobrevivência e proliferação desses microrganismos na areia.

Figura 6 - Lixo e efluentes provenientes de barracas e residências na praia de Barra Grande

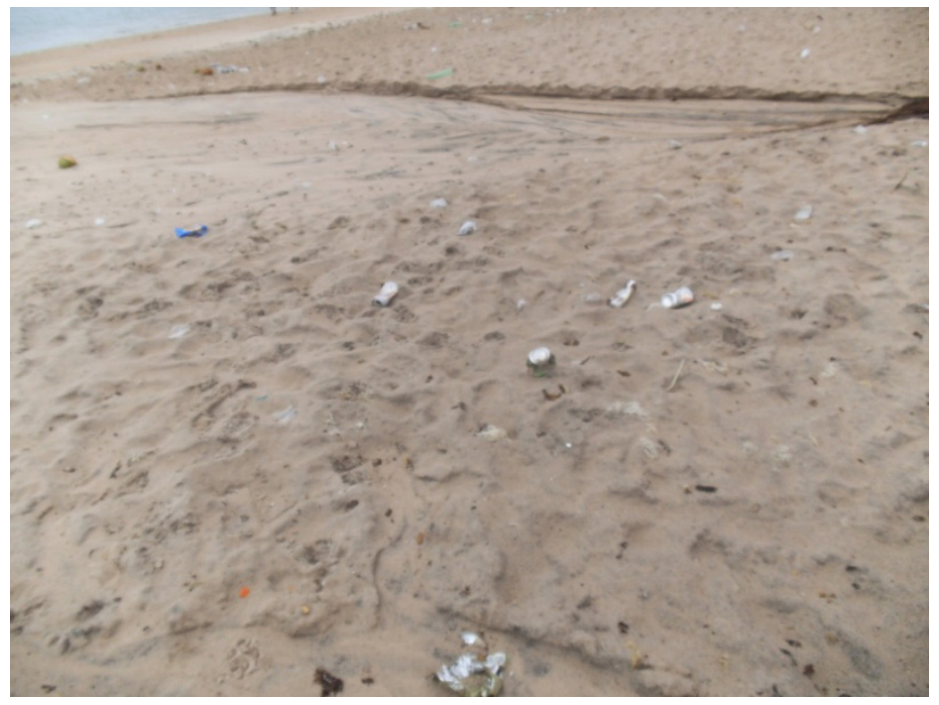

Fonte: Campanha de campo dos autores

A procedência do lixo nas praias depende muito da sua localização, da geomorfologia local, das variáveis oceanográficas e da sua utilização. Os dados revelam que a principal origem do lixo nas praias da Ilha de Itaparica é a prática turística e recreacional, seguida da atividade pesqueira, redes de drenagem e esgoto doméstico. Earll e colaboradores (1997), Balas e colaboradores (2003) e Yoon e colaboradores (2010) destacam que relacionar o lixo a sua fonte é o principal fator para diminuir ou até mesmo solucionar 
esse problema em áreas costeiras.

Assim como o lixo, outros fatores também são responsáveis pela contaminação da areia das praias. Entre eles, pode-se destacar os dejetos de animais, muito comuns nas praias de Itaparica, ausência de um sistema de coleta e tratamento dos efluentes domésticos, ocasionado as chamadas "línguas negras", a ocorrência de chuvas, entre outros.

Desta forma, os altos índices de coliformes encontrados nas areias das praias da ilha de Itaparica no período de baixa estação, podem estar também associados coma grandequantidade de lixo encontrado nas praias. Além disso, a alta umidade encontrada no período de coleta (inverno) favorece a sobrevivência desses microrganismos na areia. A presença de animais como cavalos, cachorros, pombos, entre outros, são frequentes nas praias analisadas, os quais podem ser vetores de contaminação da areia.

Os resultados obtidos com este estudo poderão auxiliar os gestores nas tomadas de decisões e no melhor gerenciamento da zona costeira da ilha de Itaparica. Além disso, os usuários destas praias devem ser incluídos neste processo de gestão, através de ações de educação ambiental que alertem para as implicações e impactos das ações antropogênicas ao longo do litoral, especialmente aquelas relacionadas com o descarte de resíduos sólidos e esgoto doméstico, permanência de animais domésticos na praia, retirada de vegetação costeira, dentre outras.

\section{CONCLUSÕES}

De maneira geral, as praias da ilha de Itaparica se apresentaram dentro da normalidade tomando-se como referência os parâmetros físicoquímicos temperatura e $\mathrm{pH}$. Tantos os valores de temperatura como de $\mathrm{pH}$ da água estiveram dentro da faixa considerada ideal pelo CONAMA para os dois períodos amostrados, com exceção dos valores de $\mathrm{pH}$ medidos em uma amostra na praia de Ponta de Itaparica, durante a alta estação.

Com relação aos parâmetros bacteriológicos, no período de alta estação as praias de Ponta de Itaparica, Ponta de Areia e Conceição tiveram suas águas enquadradas na categoria de excelente; na praia de Mar Grande, em uma das amostras, foram constatados níveis de Coliformes Termotolerantes e Coliformes Totais acima do permitido pelas Resoluções CONAMA No 274/00 e No 20/86. Na praia de Barra Grande duas amostras apresentaram alta concentração de Coliformes Totais e uma amostra apresentou altos valores de Coliformes Termotolerantes, caracterizando-a como imprópria para recreação de contato primário no período analisado.

Já para o período de baixa estação, as águas das praias de Ponta de Itaparica e Mar Grande foram enquadradas na categoria de excelente em relação aos níveis de Coliformes Termotolerantes e satisfatória em relação aos Coliformes Totais. Já as praias de Ponta de Areia, Conceição e Barra Grande tiveram suas águas enquadradas na categoria de excelente em relação aos dois parâmetros bacteriológicos.

$\mathrm{Na}$ baixa estação, foram detectadas altas concentrações de Nitrato nas amostras de água das praias de Ponta de Areia, Mar Grande, Conceição e Barra Grande. Tais concentrações podem estar relacionadas ao lançamento de efluentes domésticos, sem tratamento, em rios ou mesmo diretamente nas praias.

A análise de Coliformes Termotolerantes e Totais nas areias indicaram que todas as praias, na alta estação, foram consideradas próprias para contato primário e enquadradas na categoria de excelentes. Já no período de baixa estação, apenas as areias da praia de Barra Grande foi considerada própria.

A atividade recreacional parece ser a principal fonte de resíduos sólidos nas praias estudadas. Durante o período de alta estação foi coletado um número de itens aproximadamente 4 vezes maior do que a coleta na baixa estação. Nos dois períodos o plástico prevaleceu como principal constituinte.

Os resultados mostram que a falta de infraestrutura de coleta, tratamento e destinação final dos efluentes líquidos e dos resíduos sólidos, associado com a falta de planejamento e gestão do uso desses ambientes, tem sido a principal fonte de contaminação das suas praias.

Desta forma, se faz necessário que os órgãos competentes implementem um sistema de infraestrutura de saneamento ambiental, objetivando principalmente a diminuição das pressões sobre 
os recursos naturais. Além disso, é importante o desenvolvimento de um programa de monitoramento da água e da areia dessas praias, uma vez que a ilha de Itaparica nos meses de férias (verão), nos finais de semana e feriados prolongados, recebe um contingente muito alto de população flutuante (sem residência fixa no município).

\section{AGRADECIMENTOS}

Os autores agradecem à Associação das Crianças da Ilha pelo apoio durante os trabalhos de campo, a primeira autora agradece à CAPES pela sua bolsa de Mestrado e a segunda autora agradece ao CNPq pela sua bolsa de Produtividade em Pesquisa.

\section{REFERÊNCIAS BIBLIOGRÁFICAS}

AFIFI, S.; ELMANAMA, A.; SHUBAIR, M. Microbiological assessment of beach quality in Gaza Strip. Egyptian Journal of Medical Laboratory Sciences, Egito, v. 9, n. 1, p. 51-63, 2000.

APA - AGÊNCIA PORTUGUESA DO AMBIENTE. Monitorização da qualidade das areias em zonas balneares. Portugal: Instituto Nacional de Saúde Dr.Ricardo Jorge, 2011. 32 p.

ARAÚJO, M. C. B.; COSTA, M. F. Lixo no ambiente marinho. Ciência Hoje, Brasil, v. 32, n. 191, p. 64-67, Nov. 2003.

BAHIA. Superintendência de Estudos Econômicos e Sociais. Base cartográfica digital do estado da Bahia: mapeamento topográfico sistemático 1:100.000. Salvador: SEI, 2008.

BALAS, C. E.; ERGIN, A.; WILliAMS, A. T.; KOK, L.; DEMERCI, D. Marine litter assessment for Antalya, Turkey, beaches. In: OZHAN, E. Proceedings of the Seventh International Conference on the Mediterranean Coastal Environment. Ankara, Turkey: Middle East Technical University, v. 1, 2003. p. 1037-1046.

BENEDICT, R. T.; NEUMANN, C. M. Assessing
Oregon's twenty-six coastal beach areas for recreational water quality standards. Journal Marine Pollution Bulletin, EUA, v. 49, n. 7, p. 624-629, Out. 2004. DOI: 10.1016/j.marpolbul.2004.04.005

BIRD, E. C. F. Beach Management. New York: Wiley, 1996. 219 p.

BITAR, O. Y. Meio ambiente e geografia. São Paulo: SENAC, $2004.164 \mathrm{p}$.

BLAKEMORE, F. B.; WILliAMS, A. T. Public Valuation of Beaches in South East Wales, UK. Shore and Beach, Flórida, v. 66, n. 4, p. 18-23, Jul. 1998.

CETESB - COMPANHIA DE TECNOLOGIA DE SANEAMENTO AMBIENTAL. Relatório de qualidade das águas litorâneas no Estado de São Paulo: balneabilidade das praias. São Paulo: Cetesb, 2004. $72 \mathrm{p}$.

CONAMA - CONSELHO NACIONAL DE MEIO AMBIENTE. Resolução n. 274, de 29 nov. 2000. Dispõe sobre a qualidade das águas de balneabilidade e altera o disposto na Resolução CONAMA n. 20, 18 jun. 1986. Diário Oficial [da] República Federativa do Brasil. Poder Executivo, Brasília, DF, 29 nov. 2000. Seção I, p. 70-71, 2000.

CONAMA - CONSELHO NACIONAL DE MEIO AMBIENTE. Resolução $n$. 357, de 17 março de 2005. Dispõe sobre a classificação dos corpos de água e diretrizes ambientais para o seu enquadramento. Diário Oficial [da] República Federativa do Brasil. Poder Executivo, Brasília, DF, 18 mar. 2005. Seção I, p. 58-63, 2005.

CONAMA - CONSELHO NACIONAL DE MEIO AMBIENTE. Resolução $n^{\circ} 20$, de 18 de junho de 1986. Dispõe sobre a classificação de águas doces, salobras e salinas. Diário Oficial [da] República Federativa do Brasil. Poder Executivo, Brasília, DF, 18 jun 1986. Seção I, p. 11.356, 1996.

CORIOLANO, L. N. M. T. Turismo e a degradação ambiental no litoral do Ceará. In: LEMOS, A. I. G. 
Turismo: impactos socioambientais. São Paulo: Hucitec, 2001. p. 93-103.

DINIZ, R. F. Erosão costeira ao longo do litoral oriental do Rio Grande do Norte: causas, conseqüências e influência nos processos de uso e ocupação da região costeira. $180 \mathrm{f}$. (Doutorado em Geologia). Universidade Federal da Bahia. Salvador, 2002.

DOMINGUEZ, J. M. L.; BITTENCOURT, A. C. S. P. Geologia. In: HATGE, V.; ANDRADE, J. B. Baía de Todos os Santos: aspectos oceanográficos. Salvador: EDUFBA, 2009. p. 25-66.

EARLL, R. C.; WILLIAMS, A. T.; SIMMONS, S. L. Aquatic litter, management and prevention - the role of measurement. Medcoast, Turquia, p. 383-396, 1997.

EMBASA - EMPRESA BAIANA DE ÁGUA E SANEAMENTO. Diagnóstico dos serviços de água e esgoto. EMBASA: Salvador. Disponível em: http:// www.snis.gov.br/. Acesso em 14 dez. 2013.

EEA - EUROPEAN ENVIRONMENT AGENCY. Core Set of Indicators - Guide. Copenhagen: EEA Technical Report, v. 1, 2010. 37 p.

FULGÊNCIO, P. C. Glossário vade mecum. Rio de Janeiro: Mauad, 2007. 678p.

GLOSSARY OF ENVIRONMENT STATISTICS. New York: United Nations. Sudies in Methods Series F, v. 67, 1997. 83p.

HOLDEN, A. Environment and tourism. London: Routledge, 2000. 225 p.

IBGE - INSTITUTO BRASILEIRO DE GEOGRAFIA E ESTATÍSTICA. Contagem Populacional. IBGE: Brasília. Disponível em: http://www.ibge.gov.br/. Acesso em: 20 set. 2013.

INMET - INSTITUTO NACIONAL DE METEOROLOGIA. Normais Climatológicas - 1961 a 1990. Brasil: Ministério da Agricultura, Pecuária e
Abastecimento, $1992.155 \mathrm{p}$.

MAGINI, C.; GOMES, D.F; VERÍSSIMOA, C.U.; ANTÔNIO NETO, B.; FREIRE, G.S.S. Avaliação ambiental da praia do Futuro, município de Fortaleza - Ceará. Revista de Geologia, Ceará, v. 20, n. 1, p. 91-98, Jun. 2007.

MANCINI, L.; D'ANGELO,A. M.; PIERDOMINICI, E.; FERRARI, C.; ANSELMO, A.; VENTURI., I.; FAZZO, L.; FORMICHETTI, P.; IACONELLI, M.; PENNELLI, B. Microbiological quality of Italian beach sands. Microchemical Journal, Louisiana, v. 79, n. 1, p. 257-261, Jan. 2005. DOI: 10.1016/j. microc.2004.10.013

MENDES, B.; OLIVEIRA, J. F. S. Qualidade da água para consumo humano. Lisboa: Lidel - Edições Técnicas, 2004. 617 p.

MIDAGLIA, C. L. V. Turismo e Meio Ambiente no Litoral Paulista: Dinâmica daBalneabilidade das Praias. In: LEMOS, A. I. G. Turismo: Impactos Socioambientais. São Paulo: HUCITEC, 2001. p. 33-56.

MORGAN, R. Preferences and Priorities of Recreational of Beach Users in Wales, UK. Journal of Coastal Research, Lawrence, v.15, n. 3, p. 653-667, Mai. 1999.

NASCIMENTO, L. Comportamento da Linha de Costa nos últimos 50 anos e o risco de prejuizos econômicos na face oceânica da Ilha de Itaparica, Bahia. $123 \mathrm{f}$. (Doutorado em Geologia). Universidade Federal da Bahia. Salvador, 2012.

OLIVEIRA, A. L.; TESSLER, M. G.; TURRA, A. Distribuição de lixo ao longo de praias arenosas Estudo de caso na praia de Massaguaçu, Caraguatatuba, SP. Revista de Gestão Costeira Integrada, Portugal, v. 11, n.1, p. 75-84, Mar. 2011.

ROCA, E.; VILLARES, M.; ORTEGO, M. I. Assessing public perceptions on beach quality according to beach users' profile: a case study in the

Soc. \& Nat., Uberlândia, 27 (3): 469-484, set/dez/2015 
Costa Brava (Spain). Tourism Management, Nova Zelândia, v. 30, n. 4, p. 598-607, Ago. 2009. DOI: 10.1016/j.tourman.2008.10.015

SILVA, I.R.; SOUZA FILHO, J.R.; BARBOSA, M.; REBOUÇAS, F.; MACHADO, R.S. Diagnóstico Ambiental e Avaliação da Capacidade de Suporte das Praias do Bairro de Itapoã, Salvador, Bahia. Revista Sociedade e Natureza, Uberlândia, v. 21, n. 1, p. 7184, Abr. 2009.

SOARES, M. O.; PAIVA, C. C.; GODOY, T.; SILVA, M. B. Atol das Rocas (Atlântico Sul Equatorial): um caso de lixo marinho em áreas remotas. Revista de Gestão Costeira Integrada, Portugal, v. 11, n. 1, p. 149-152, Mar. 2011.

UNEP/IOC/FAO. Report of the IOC/FAO/UNEP review meeting on the persistent synthetic materials pilot survey. Programme for pollution monitoring and research in the Mediterranean. Athens: UNEP, 1989. 113p.

UNEP. Marine litter: A global challenge. Nairobi: UNEP, 2009. $232 \mathrm{p}$.

VALLE, C. E. do. Qualidade ambiental: o desafio de ser competitivo protegendo o meio ambiente. São Paulo: Pioneira, 1995. 139 p.

WILLIAMS, A.T.; NELSON, C. The Public Perception of Beach Debris. Shore and Beach, Flórida, v. 62, n. 2, p. 17-20, Jun. 1997.

YOON, J. H.; KAWANO, S.; IGAWA, S. Modelling of marine litter drift and beaching in the Japan Sea. Marine Pollution Bulletin, EUA, v. 60, n.3, p. 448-463, Mar. 2010. DOI: 10.1016/j.marpolbul.2009.09.033 